\title{
Thymic Typical Carcinoid Tumor
}

National Cancer Institute

\section{Source}

National Cancer Institute. Thymic Typical Carcinoid Tumor. NCI Thesaurus. Code C45720.

A primary thymic carcinoid tumor, characterized by the presence of uniform, polygonal neoplastic cells, a low mitotic rate, and absence of necrosis. 